\title{
Ring lesions in the brain: a harmless commensal?
}

\author{
Justin Garner, ${ }^{1}$ Robin Howard ${ }^{2}$
}

${ }^{1}$ Department of Respiratory Medicine, Watford General Hospital, Watford, UK

${ }^{2}$ Department of Neurology, St Thomas' Hospital, London, UK

\section{Correspondence to} Dr Justin Garner, justin.garner@nhs.net justingrnr@googlemail.com

\section{DESCRIPTION}

A 72-year-old gentleman, type 2 diabetic, was admitted in the hospital with a head injury which was a result of a fall. Several weeks before, he had been investigated and treated for a communityacquired pneumonia, left pleural effusion and confusion. CT brain showed right frontal encephalomalacia.

On re-examination, drowsiness, extensor plantar responses and signs of a left pleural effusion were recorded. He was afebrile.

His white cell count was $12.3\left(4.0-11.0 \times 10^{9}\right)$, neutrophils $10.8\left(1.5-7.0 \times 10^{9}\right)$, C reactive protein 5 (0-4) $\mathrm{mg} / \mathrm{l}$, urea $5.0(1.7-8.3) \mathrm{mmol} / \mathrm{l}$ and glucose $6.8(4.0-7.0) \mathrm{mmol} / \mathrm{l}$. Repeat CT and MRI scans of the brain revealed 'new multiple bi-hemispheric ring-enhancing lesions', thought to represent abscesses (figure 1). ${ }^{1}$ Blood cultures were sterile. Transthoracic echocardiogram was normal. A persisting pleural effusion was noted: aspirate of

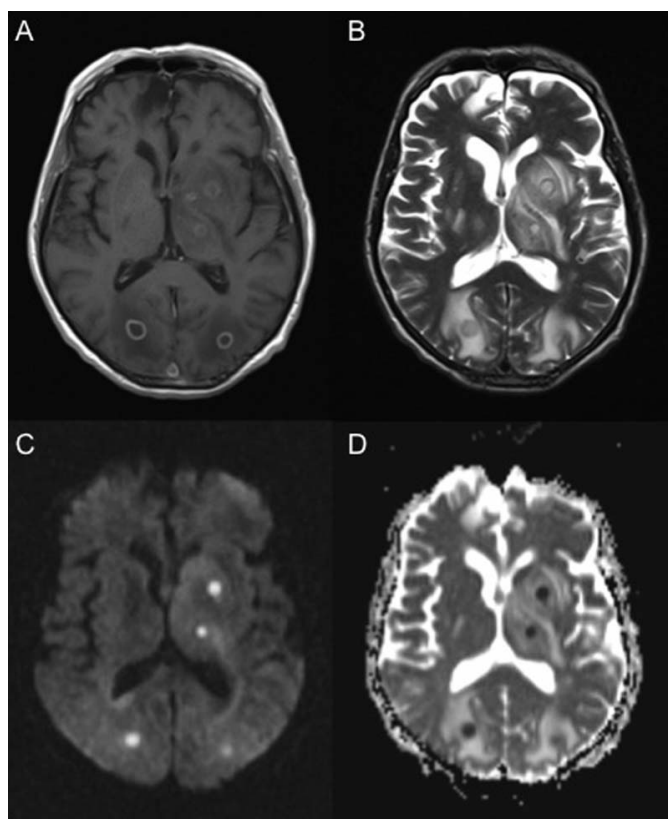

Figure 1 (A) Gadolinium-enhanced T1-weighted axial MRI showing multiple small ring-enhancing lesions within both cerebral hemispheres including the left basal ganglia and thalami. (B) On T2-weighted axial MRI, these lesions have high $\mathrm{T} 2$ signal centrally with a rim of low T2 signal and surrounding oedema. (C) The lesions have high central signal on diffusion-weighted MRI with corresponding restriction on the apparent diffusion coefficient map (D), in keeping with cerebral abscesses. pus revealed Gram-positive cocci identified as Streptococcus milleri on PCR.

He was prescribed a 6-week course of intravenous ceftriaxone, oral metronidazole and a short course of dexamethasone. Continuing clinical and radiological improvement has been documented up to 12 weeks.

The causes of ring-enhancing lesions include infection (eg, pyogenic, tuberculosis, toxoplasmosis and neurocisticercosis), inflammation (eg, sarcoidosis) and malignancy (eg, lymphoma). ${ }^{1}$ MRI is the non-invasive modality of choice to characterise cerebral lesions. Restricted diffusion (of water molecules) in an abscess is a feature aiding differentiation from centrally necrotic tumours; however, it is not pathognomonic. Microbiological diagnosis is crucial, and is dependent on adequate sampling, including for anaerobes, of bronchial secretions, blood and pus, before antimicrobial therapy. ${ }^{2} 3$ A biopsy of a brain lesion may be necessary. Unrecognised brain abscess is fatal.

\section{Learning points}

- MRI is the non-invasive modality of choice to characterise cerebral lesions.

- However, distinguishing brain abscesses and multiple metastases is challenging: a biopsy of a brain lesion may be necessary.

- The Streptococcus milleri group of commensals, inhabiting the oropharynx, gut and vagina, is increasingly recognised as an important cause of brain abscess and empyema in compromised individuals, for example, diabetics, alcohol-dependents, etc.

Contributors JG contributed to the concept and drafting the article and RH performed the critical revision.

\section{Competing interests None.}

Patient consent Obtained.

Provenance and peer review Not commissioned; externally pee reviewed.

\section{REFERENCES}

1 Garg RK, Sinha MK. Multiple ring-enhancing lesions of the brain. J Postgrad Med 2010;56:307-16.

2 Wong CA, Donald F, Macfarlane JT. Streptococcus milleri pulmonary disease: a review and clinical description of 25 patients. Thorax 1995:50:1093-6.

3 Carpenter J, Stapleton S, Holliman R. Retrospective analysis of 49 cases of brain abscess and review of the literature. Eur J Clin Microbiol Infect Dis 2007;26:1-11. 
Copyright 2013 BMJ Publishing Group. All rights reserved. For permission to reuse any of this content visit http://group.bmj.com/group/rights-licensing/permissions.

BMJ Case Report Fellows may re-use this article for personal use and teaching without any further permission.

Become a Fellow of BMJ Case Reports today and you can:

Submit as many cases as you like

- Enjoy fast sympathetic peer review and rapid publication of accepted articles

- Access all the published articles

- Re-use any of the published material for personal use and teaching without further permission

For information on Institutional Fellowships contact consortiasales@bmjgroup.com

Visit casereports.bmj.com for more articles like this and to become a Fellow 